\title{
OPINIONS AND BEHAVIOR OF STUDENTS ABOUT ABUSE OF INTERNET IN SOCIAL INVOLVMENTS: GENDER ANALYSIS
}

\author{
Borislav Jošanov", Novi Sad Business School, Serbia \\ Andreja Pucihar, Faculty of Organizational Sciences, Kranj, Slovenia \\ Ivana Jošanov Vrgović, Novi Sad Business School, Serbia \\ Zoran Marošan, Novi Sad Business School, Serbia
}

\begin{abstract}
New Internet technologies brought new gamma of interests worldwide. In the focus of people are social networks, main usage and the abuse of Internet usage. Authors analyze the group of students in Higher School for Professional Business Studies in in Novi Sad, Serbia, and in Faculty of Organizational Sciences Kranj, Slovenia. In the focus of this research are opinions and behavior of students about social aspects of Internet general usage, and specificly opinions about social networks and WikiLeaks. This paper is the succesor of the sross-cultural research that was presented in this journal with the same data two years ago, but structured diferently, acording to the location where they were taken. Results of this research are analyzed and presented according to the gender of examinees.
\end{abstract}

Key-words: Internet, gender, social networks, WikiLeaks, abuse

JEL classification: $D 83$

\section{STAVOVI I PONǍ̌SANJE STUDENATA O ZLOUPOTREBI INTERNETA U DRUŠTVENIM DOGAĐANJIMA: ANALIZA PREMA POLOVIMA}

Sažetak: Nove Internet tehnologije donele su novi spektarinteresovanja u celom svetu. U centru pažnje ljudi su društvene mreže, njihovo osnovno korišćenje i zloupotreba. Autori analiziraju grupu studenata Visoke poslovne škole strukovnih studija iz Novog Sada, Srbija i Fakultete za organizacijske vede iz Kranja, Slovenija. U centru pažnje ovog istraživanja sustavovi i ponašanjastudenata o društvenim aspektmai generalnog korišćenja Interneta, a posebno društvenih mreža i Vikiliksa. Ovaj rad je sledbenik

\footnotetext{
*borislavjosanov@sbb.rs
} 
kros-kulturalnog istraživanja predstavljenog u ovom časopisu pre dve godine, ali strukturiranog drukčije, prema lokaciji gde su preuzeti. Rezultati ovog istraživanja su analizirani i prezentovani prema polu ispitanika.

Ključne reči: Internet, pol, društvene mreže, Vikiliks, zloupotreba

\section{INTRODUCTION}

Technically, the Internet can be described as a global system of interconnected computer networks, where the web is the most important service, developed as a complex product of modern technologies. Different information media newspaper, book and other print publishing found their place in the web environment.

Because of the worldwide presence and easy ways of communication, the Internet brings far away people much closer. Global usage of Internet services in the last years is leading world to enter the geo-information age (Gardels, 2011).

In the focus of the research described in this paper made the research are different attitudes of students mainly about social networks and WikiLeaks, with participants in two countries: Serbia and Slovenia. The conducted research has two independent variables: the country where the student lives and his/her gender. The results with the first variable was already presented in (Jošanov et al., 2014), while in this paper are the results according the gender of examinees.

\section{SOCIAL NETWORKING AND WIKILEAKS}

Network with nodes (people) and ties (relationships between them) is used for virtual communication. This kind of structures we call social networks (SN) and they are redefining the way people communicate. That new kind of communication, brought by $\mathrm{SN}$, has moved from niche phenomenon to mass adoption. Since their introduction, social networks have attracted millions of users, where many of them have integrated this type of sites into their daily practices. Boyd and Ellison (2008) define social networks as "web-based services that allow individuals to construct a public or semi-public profile within a bounded system, articulate a list of other users with whom they share connection, and view and traverse their list of connections made by others within the system". It refers to the relationships that exist between networks of people. The SNS concept is to map relations between people and to look for information which will help to understand how those relations work, information flows and organizations collaborate (Cross, \& Parker, 2004). 
13 | OPINIONS AND BEHAVIOR OF STUDENTS ABOUT ABUSE OF INTERNET IN SOCIAL INVOLVMENTS: GENDER ANALYSIS

SN sites allow people to make their presentations and create connections with others, while Facebook is especially good in the bridging between people (Ellison et al., 2007). That fact pushed Facebook to the world leader in this kind of linking and communication among the people worldwide, especially among the younger generations.

According to Haferkamp and Kramer (2011), "the process that happens when an individual is confronted with numerous other SNS profiles is social comparison, as the result of information diversity that is provided by these profiles, offering a perfect basis for engaging in comparisons with others".

There are different ways in SNS systems to let their users create profiles and connections with others, who are usually called "friends" (Lampe et al., 2006). Facebook has the presence of celebrities and public figures, and the ability to be "friend" with them becomes very popular (Kujath, 2011).

Using those tools, people were linking people in closed groups to communicate among the group members during the people uprisings in Arabic countries. This new kind of SNS usage creates new political dimension and new opinions about the core idea of SNS usage.

The main goal of WikiLeaks is to bring and publish important news and information with new stories, helping people find evidence of the truth. For that purpose, they formed anonymous, strong and secure and channels to get important information. Also, they are taking information about their sources in secret and they are not censoring those materials.

Published documents from WikiLeaks information insurgency in the last period have included 76,000 secret Afghanistan war documents, 392,000 files from the Iraqi war and more than 250,000 United States embassy cables. The case about the leaks from Vietnam War brought the principle about legality to leak secrets, but not to publish leaks and WikiLeaks founder Julian Assange is marked as a high-tech terrorist, while senator Joe Lieberman advocates that U.S. newspapers could still be punished for publishing WikiLeaks' leaks and that USA has to change her espionage laws to convict Julian Assange.

\section{FRAMEWORK OF THE RESEARCH}

This research uses the information taken from the group of students in Kranj, Slovenia and Novi Sad, Serbia. The same information is used in other research, presented in (Jošanov et al., 2014).

As the research main instruments, questionnaire with 10 questions was created, using also two independent variables: the country where the student lives and her/his gender. This instrument is created with the closed groups of 5 answers for each question. The complete research instrument is included in 10 tables 
presented in this paper. The results of this research structured according to the first independent variable are presented in (Jošanov et al., 2014), while this research analyzes correlations of the answers with the second independent variable.

The idea of this research is to take information about opinions regarding social networks, responsibility for information on the Internet and the WikiLeaks role about presenting secret information worldwide. The answers to the questions are structured to examine these topics according to the gender of examinees, as an obvious category which could have some implications on student's opinions.

After the investigation campaign, authors collected 140 completely fulfilled questionnaires. In the complete sample, we have found 61 answers of female and 79 of male population among these two groups of students.

Processing of those questions was taken with Microsoft Excel and presented in 10 tables, containing five levels of answers, according to the gender of participants. The authors also calculated Pearson product-moment correlations (PPMCC) between two groups of results.

\section{RESEARCH RESULTS}

Looking at the results about SN usage, we found that male students are more reluctant for total openness (more than six times), while they are also using SN in significantly higher percentage (Table 1).

Table 1

SN usage

\begin{tabular}{lcc}
\hline Using of SN & Male $\%$ & Female \% \\
\hline Non-users & 4.9 & 10.1 \\
Just looking, don't communicate & 9.8 & 5.1 \\
Communication only with well-known persons & 68.9 & 55.7 \\
Taking part in interesting groups & 13.1 & 7.6 \\
Ready for communication with everyone & 3.3 & 21.5 \\
\hline
\end{tabular}

Note. Compiled by author.

When we analyzed results of SN usage in revolutionary movements, we have found that both female and male students prefer the attitude that it is important who is using SN, while significantly more liberal attitudes or without opinion are among female students (Table 2). 
15 | OPINIONS AND BEHAVIOR OF STUDENTS ABOUT ABUSE OF INTERNET IN SOCIAL INVOLVMENTS: GENDER ANALYSIS

Table 2

Revolutionary movements and SN usage

\begin{tabular}{lcc}
\hline Using SN in the revolutionary movements & Male \% & Female \% \\
\hline It is pure abuse & 8.2 & 12.7 \\
It depends on who uses them & 32.8 & 31.5 \\
Without opinion about this & 34.4 & 22.8 \\
It is normal use & 16.4 & 16.5 \\
It is very helpful & 8.2 & 16.5 \\
\hline
\end{tabular}

Note. Compiled by author.

Both genders have dominant opinion that Web contents must have personal responsibility of the authors (Table 3 ), much more among male students. The next rated answer among female students is that the criteria has to be taken from the low system, while male students prefer censorship and authorization of information.

Table 3

Web contents management

\begin{tabular}{lcc}
\hline The authors of web information & Male \% & Female \% \\
\hline Are responsible for those information & 73.7 & 46.8 \\
The subject of censorship & 8.2 & 7.6 \\
Need some authorization & 6.6 & 3.8 \\
Have responsibility only when they break the law & 4.9 & 25.3 \\
Are completely free for publishing & 6.6 & 16.5 \\
\hline
\end{tabular}

Note. Compiled by author.

The idea that Internet contents have to remain absolutely open for use is dominant among female population. Almost the same relation of answers we have found for the idea that contents on web contents should be presented without any control procedure. Male students prefer attitude that origin of information is obligatory on each site (Table 4).

Table 4

Censorship of contents

\begin{tabular}{lcc}
\hline Web contents & Male $\%$ & Female $\%$ \\
\hline Need formal approve & 13.1 & 7.6 \\
Origin of information is obligatory on each site & 36.1 & 26.6 \\
Without opinion about web contents & 3.3 & 3.8 \\
Should be presented without any control procedure & 18 & 24 \\
Web contents have to remain absolutely open & 29.5 & 38 \\
\hline
\end{tabular}

Note. Compiled by author. 
Internet traffic control is the question strongly differentiated genders (Table 5). We have found that two first positions are the dominant answers in all categories of results (traffic must be controlled or, at least, checked in special cases). Almost a half of male examinees think that traffic need strong control (45.9\%) while female students put obligatory control only in special cases at first place. Male students have very low percentage level with opinions that there is not need for control or that traffic has to be anarchic: only $6.6 \%$, while situations among female students is significantly different: $24 \%$ of them suggest one of these 2 answers.

Table 5

\section{Traffic control}

\begin{tabular}{lcc}
\hline Internet traffic & Male $\%$ & Female \% \\
\hline Need strong control & 45.9 & 25.3 \\
Control is obligatory only in special cases & 41 & 44.3 \\
Without opinion about this & 6.5 & 6.4 \\
Without control & 3.3 & 13.9 \\
Has to stay completely anarchic & 3.3 & 10.1 \\
\hline
\end{tabular}

Note. Compiled by author.

Internet abuse has very similar results (Table 6). Thus, highest ranks of answers among male students have the opinion that it needs vigorous prosecution, while among female population dominant selection is that it needs sanctions only in the case of intended robbery. Those are the most popular answers in both groups. After that, authors found similar percentages in both groups for the opinion that main reason for abuse is the consequence low level of victims' protection.

Table 6

\section{Abuse on Internet abuse}

\begin{tabular}{lcc}
\hline Abuse on Internet & Male \% & Female \% \\
\hline Need vigorous prosecution & 45.9 & 26.6 \\
need sanctions in the case of robbery & 27.9 & 53.2 \\
Without opinion about this & 8.2 & 2.5 \\
It is caused by of the poor victims' protection & 14.7 & 16.5 \\
Doesn't need prosecution in this anarchic environment & 3.3 & 1.2 \\
\hline
\end{tabular}

Note. Compiled by author.

WikiLeaks and it's leader Julian Assange are the subject of last four questions. Female students has much better information about WikiLeaks. The only group with an option with zero answers in whole research was taken among male students, where none of them is very interested in that (Table 7). 
17 | OPINIONS AND BEHAVIOR OF STUDENTS ABOUT ABUSE OF INTERNET IN SOCIAL INVOLVMENTS: GENDER ANALYSIS

Table 7

Information about WikiLeaks

\begin{tabular}{lcc}
\hline I know about WikiLeaks & Male \% & Female \% \\
\hline Almost anything & 34.4 & 8.9 \\
Just a little bit & 36.1 & 27.8 \\
Moderately & 21.3 & 44.3 \\
A lot & 8.2 & 13.9 \\
A lot, very interesting theme & 0 & 5.1 \\
\hline
\end{tabular}

Note. Compiled by author.

The very high rank among female students is found for the option that WikiLeaks acts as moderately useful service. Male students dominantly think that acting of WikiLeaks is neither harmful nor beneficial (Table 8). High ranks among female students have been found for the opinion that WikiLeaks actions are very useful, while this option is half time less popular among male students.

Table 8

WikiLeaks as useful service

\begin{tabular}{lcc}
\hline Are WikiLeaks actions & Male $\%$ & Female $\%$ \\
\hline Very harmful & 13.1 & 1.2 \\
Moderately harmful & 3.3 & 7.6 \\
Neither harmful nor beneficial & 47.6 & 15.2 \\
Moderately useful & 26.2 & 49.4 \\
Very useful & 9.8 & 26.6 \\
\hline
\end{tabular}

Note. Compiled by author.

If we look all the answers in this investigation, the most of students choose the option that WikiLeaks doesn't have to prohibit or help (Table 9). Next rank among female students has been found for the option that they would like to sponsor and supply with information, while male students prefer the option to sponsor WikiLeaks, but not to supply it with information. Almost seven times more male students think that WikiLeaks has to be forbidden.

Table 9

WikiLeaks work

\begin{tabular}{lcc}
\hline I thing that WikiLeaks needs to & Male \% & Female \% \\
\hline Forbid to work & 8.2 & 1.2 \\
Sanction by court & 3.3 & 2.5 \\
Neither prohibit nor help & 68.8 & 67.1 \\
Sponsor & 13.1 & 12.7 \\
Sponsor and supply with information & 6.6 & 16.5 \\
\hline
\end{tabular}

Note. Compiled by author. 
Last question took the opinions about Julian Assange. Dominant opinion is that he is more positive than negative, much more among female students (Table 10), where more than a half of examinees have positive opinion. Very high rank in both groups has the opinion he is not relevant person, dominantly among male students. Among male students authors also found more than three times higher ranks that Assange is dominantly harmful. Very similar relation authors found for the option that Assange is more negative than positive.

Table 10

Julian Assange as a person

\begin{tabular}{lcc}
\hline I see Julian Assange as & Male $\%$ & Female $\%$ \\
\hline Dominantly harmful & 13.1 & 3.8 \\
More negative than positive & 11.5 & 5.1 \\
Not relevant person & 34.4 & 32.9 \\
Useful person in this time & 31.2 & 41.7 \\
Future Nobel Peace Prize & 9.8 & 16.5 \\
\hline
\end{tabular}

Note. Compiled by author.

We have found high level of Pearson product-moment correlation coefficient between those 2 groups of analyzed results: it is PPMCC $=0.75$.

\section{TYPICAL PROFILES}

When the authors used mode for prototyping typical opinions taken from those answers, they have found typical profiles.

This imaginary female person:

- takes communication only with well-known persons,

- thinks that SN usage in the revolutionary movements depends on who uses them,

- her opinion is that authors are responsible for those information,

- web contents have to remain absolutely open,

- traffic control is obligatory only in special cases,

- abuse on Internet need sanctions in the case of robbery,

- she has moderate information about WikiLeaks,

- WikiLeaks is moderately useful,

- thinks that WikiLeaks doesn't have to neither prohibit nor help, and

- Julian Assange is useful person in this time.

Typical male student differs from this typical female student in next facts:

- he is without opinion about SN usage in the revolutionary movements,

- origin of information is obligatory on each site,

- traffic on Internet needs strong control,

BUSINESS SCHOOL, 1/2016, 11 - 21 
19 | OPINIONS AND BEHAVIOR OF STUDENTS ABOUT ABUSE OF INTERNET IN SOCIAL INVOLVMENTS: GENDER ANALYSIS

- Internet abuse should be vigorously prosecuted,

- He has a little information about WikiLeaks,

- acting Wikileaks he consider neither harmful nor beneficial, and

- Julian Assange is irrelevant person.

Authors also analyzed 4 groups of answers: female Slovenian and Serbian students and male Serbian and Slovenian students. When we formed typical profiles with the highest numbers of answers, we have found following differences:

- The only difference between Slovenian female and male typical answers is that largest group of Slovenian female student thinks that Internet abuse should be vigorously prosecuted, while typical Slovenian male student thinks that it should be sanctioned in the case that person intended to make robbery.

- On the other hand, we have found more differences between Serbian female and male typical answers. Among female students the most frequently answers are that traffic on the Internet must be controlled, Internet abuse should be vigorously prosecuted, and WikiLeaks actions are neither harmful nor beneficial, while male students in Serbia dominantly think that traffic on Internet should be checked only in special cases, Internet abuse should be sanctioned in the case that person intended to make robbery, and WikiLeaks actions are moderately useful.

- Differences between typical answers between male students in Serbia and Slovenia are also found in 4 questions. Male students in Serbia don't have opinion about using social networks in the revolutionary movements, they think that available contents on the web should remain entirely free, they know a little about WikiLeaks, and in their opinion Julian Assange is irrelevant., while male students in Slovenia think that it depends who is using social networks in the revolutionary movements, at available contents on the web must show the origin of information, they know moderately about WikiLeaks, and in their opinion Julian Assange is that he ) very useful for the modern world.

- $\quad$ Finally, differences between typical answers between female students in Serbia and Slovenia are found in 5 questions, where we have the same differences that are present among male students in these 2 countries. The remaining different answers are found about WikiLeaks actions. Female students in Slovenia that they are moderately useful, while in Serbia we have found opinion among female students that these actions are neither harmful nor beneficial. 


\section{CONCLUSIONS}

The main fact found in this research that the opinions depend on the gender of examinees.

When we speak about the role of gender in these results, we would like to put just a few facts about the differences that we found. First, we have found that male students use Facebook little more than male students, but female students are much more open for that kind of communication, what is in line with the results of Lenhart and Madden (2007).

This leads us to the actual problem in the world about usage of Facebook: the abuse of female users. Social networks are suitable places for women to be victims of cyber crime (Tsedu, 2012). The results of this research show that female users are easy target for that, because even $21.5 \%$ of them (6.5 times more than male students) are very open to communicate with everyone. We also found that there are 19.1\% of female students in Slovenia and 25\% in Serbia with this risky attitude. The reasons for this difference we could find the different social, cultural, educational and historical states in these countries.

Female examinees are more about to think that $\mathrm{SN}$ usage in revolutionary movements in extreme categories, while male students are dominantly without opinion about that, or they are ready to mitigate their attitudes.

We also found that male students have much more interest for personal responsibility for Internet contents, the presentation of content origin, and strong prosecutions, while female students prefer the idea to be free to publish their contents, without publishing procedures, and sanctions only in the cases of robbery. These facts are in line with the results of some appropriate gender researches (Mesch, 2005; Bonetti, Campbell, \& Gilmore, 2010).

Male students know less about WikiLeaks and they have worse opinion about its role, future and about Julian Assange, what is in line with the male's commitment to the procedures, low and order on one side, while we have more open ideas on the female's side.

\section{REFERENCES}

Bonetti, M., Campbell, M.A., \& Gilmore, L.A. (2010). The Relationship of Loneliness and Social Anxiety with Children's and Adolescents' Online Communication. CyberPsychology, Behavior, and Social Networking, 13(3), 279-285.

Boyd, D.M., \& Ellison, N.B. (2008). Social Network Sites: Definition, History, and Scholarship. Journal of Computer-Mediated Communication, 13(1), 210-230. 
21 | OPINIONS AND BEHAVIOR OF STUDENTS ABOUT ABUSE OF INTERNET IN SOCIAL INVOLVMENTS: GENDER ANALYSIS

Cross, R., \& Parker, A. (2004). The Hidden Power of Social Networks: Understanding How Work Really Gets Done in Organizations. Harvard Business School Press.

Ellison, N.B., Steinfield, C., \& Lampe, C. (2007). The Benefits of Facebook 'Friends: " Social Capital and College Students' Use of Online Social Network Sites. Journal of Computer-Mediated Communication, 12, 1143-1168.

Gardels, N. (2011). Welcome to the Geo-Information Age. New Perspectives Quarterly, 28(1), 2-5.

Haferkamp, N., \& Kramer, N.C. (2011). Social Comparison 2. O: Examining the Effects of Online Profiles on Social-Networking Sites. Cyberpsychology, Behavior, and Social Networking, 4(5), 309-314.

Jošanov, B., Pucihar, A., \& Jošanov-Vrgović, I. (2014). Opinions and behavior of students in Social aspects of Internet use in Serbia and Slovenia. Škola biznisa, 1, 18-33.

Kujath, C.L. (2011). Facebook and MySpace: Complement or Substitute for Face-to-Face Interaction?, Cyberpsychology. Behavior, and Social Networking, 14(1-2), 75-78

Lampe, C., Ellison, N., \& Steinfield, C. (2006). A Face(book) in the Crowd: Social Searching vs. Social Browsing. In:Proceedings of the 20th conference on Computer supported cooperative work CSCW. 167-170.

Lenhart, A., \& Madden, M. (2007). Social networking websites and teens: An overview (pp. 1-7). Pew/Internet.

Mesch, G. (2005). A study of adolescents' online and offline social relationships. Oxford, England: Oxford Internet Institute. Retrieved from www.oii.ox.ac.uk=research=publications=RR8.pdf

Tsedu, T. (2012). The rise of cyber abuse. Retrieved from http://m.news24.com/women24/Wellness/BodyAndSpirit/Mediaattention-needed-for-cyber-abuses-2011112

Received: 21.03.2016.

Accepted: 09.06.2016. 